\title{
Service quality moderate TQM practice towards success of service performance
}

\author{
Chong Chiz Chzee, Rushami Zein Bin Yusof \\ College of Business, University Utara Malaysia PO box 06010, UUM Sintok, Kedah Darul Aman, Malaysia \\ College of Business, University Utara Malaysia PO box 06010, UUM Sintok, Kedah Darul Aman, Malaysia
}

\begin{abstract}
OUTSOURCING has become an important source of competitive advantage, especially in total quality approach. To maintain a competitive advantage in outsourcing, firms must enhance their ability to plan, take action, manage, and control product services and information from supplier to customer as an integrated process, rather than as a series of discrete functions. From a service partner perspective, QMP is a value-added process that is intentionally used to enhance organizational cooperative advantages and to provide low-cost product or service differentiation and focused strategies. However, the focus has generally been on the impact, due to the use of comprehensive measurement (e.g. financial/no financial measures, ex-ante/post-ante measures, quantitativel qualitative measures) on the individual, group or organizational performance. For service providers, outstanding performance is reflected in outsourcing outcomes that are responsibility, trust, and quanxi defined by the operations. A comprehensive literature review reveals that there is a lack of study of organizational performance in service management (SM) and in particular on the effects and implications of QMP organizational effectiveness and relationship management in retails and SM. Based on the literature review, this study develops a research model from organizational theory to elaborate the cause and effect relationship between service performance, organizational effectiveness, and relationship management with service partners.
\end{abstract}

Purpose - the purpose of this paper is to explore the concept and significance of the quality management practices in organizational requirements, provide ways to meet the targets and be consistently monitoring business performance.

Design/ methodology/ approach - Empirically to test certain hypotheses values with respect the quality management practice and service performance of the study objective. This is nature correlation study. Therefore, this cross-functional development study involves surveying the perception of respondents in Malaysian retailing using the revised measurement scale. Adopted from the Masahiro and Yoshida, (2005) phenomenon sets for favoured better understanding. Importantly refer to Masahiro and Yoshida, (2005) that the cross-sectional unique features learning is the Deming management philosophy which has contributed to the improvement of the Japanese products and services is summarised as follows: first of all, to improve quality by reducing machine troubles and mishandling that enables cost reduction. Secondly, refer to Yuen, (2006) with better quality and competitive prices, resulting in increasing sales, profitability and employment even achieving more market-share. Deming's quality management philosophy was examined in light of businesses practices in Japan as refer to Yoshida, (1995).

Research limitations/ implications - This research has a limited budget and times constraint, the researcher personally collected the data. Respondents were asked to answer questions from the structured questionnaires. The data was collected using satisfied random sampling among the top/medium management staffs. The researcher had recruited manages which who have marketing expertise and well customer experience. Moreover that, the management staffs need to have experiences with business environment climates especially marketing holistic, or possible do had running any business consultant or had conducted any market research for certain current organization/firm to improve business performance. Be nota that the managers well deeply understanding service quality. Therefore retailer should find ways to satisfy them and retain them for business. Originality/ value - The literature paper contributes by offering new insights on the implementation QMP in service organizations and their effectiveness with performance.

Keywords QMP, service performance, outsourcing

Paper type literature paper

\section{Introduction retailing Industries}

Traditional retails businesses based on customer satisfaction (Anderson et al., 1994). Customer satisfaction is the degree to which the customer believes that the expectations are met (Hofstede's, 2001). This assumption is no longer valid however invalidate the usefulness of the SERVQUAL items to develop alternate measures of service quality (Cronin, Taylor, 1992; Brown, Churchill, \& Peter,1993).Many researchers (Zahorik, Rust, 1992; Greising, 1994; Cornin \& Taylor, 1992) had shown that the SERVQUAL items must be customized to the 
service setting the question. The relationship between service quality and performance outcomes has been a focal point of interest in the service quality management literature (Carman, 1990; Finn \& Lamb, 1991; Brown, Churchill, \& Peter, 1993). Interestingly research has shown that the link between service quality and business performance is neither straightforward nor simple (Zahorik, Rust, 1992; Greising, 1994; Holmlund, 2007). Indeed Cornin and Taylor, (1992) found that their performance-based measure of service quality was an antecedent of customer satisfaction and that customer satisfaction exerted a stronger influence on purchase intention than did service quality.

This paper aims to provide a QMP framework that emphasis on continuous improvements for quality measurement in competitive retailing. Following a theoretical study of the dimensions of quality management in this environment, the paper reports on the literature research carried out from the past study. QMP philosophies and the comparative analysis of QMP adoption in industry versus retailing provide the theoretical and practical background for this work.

\subsection{Service quality}

According to Hasan and Kerr's (2003) claimed that quality management framework based on the attribute theory of service quality was used to show how the organizational performance is affected by various quality dimensions. The construct of quality in the services literature focuses on perceived quality, which is defined as a consumer's judgment about an entity's overall excellence or superiority (Zeithaml, 1987). This approach differs from that of objective quality, which involves an objective assessment of activity or event. Perceived quality is a form of "attitude", resulting from a comparison of expectations with perceptions of performance. However, despite the emphasis in the literature on this approach, perceived service quality has remained an elusive concept (Brady and Cronin, 2001; Parasuraman et al., 1985).

Many have suggested that quality results from a comparison of perceived performance with expected performance - based on the so-called "disconfirmation paradigm". Indeed, this notion was the basis for the SERVQUAL model, which views service quality as the gap between the expected level of service and customer perceptions of the level received (Parasuraman et al., 1988). SERVQUAL identified five determinants of service quality:

(1) Reliability;

(2) Assurance;

(3) Tangibles;

(4) Empathy; and

(5) Responsiveness.

Conceptually, these constructs address, respectively, performance standards, expertise and physical elements of the facility, employees' willingness to assist in a timely manner with their knowledge, and sensitivity. Although SERVQUAL has been extensively used in assessing services quality, it has also been subject to criticism in various respects - including its use of the "difference score", its dimensionality, its applicability, and so on (Asubonteng et al., 1996; Buttle, 1996; Cronin and Taylor, 1992; Carman, 1990; Babakus and Boller, 1992).

In addition, SERVQUAL has also been criticised for focusing solely on the service-delivery process (Gro"nroos, 1990; Mangold and Babakus, 1991; Richard and Allaway, 1993). In this respect, it is of interest that one of the underlying themes of SERVQUAL was that: "Quality evaluations are not made solely on the outcome of service; they also involve evaluations of the service delivery process" (Parasuraman et al., 1985). However, despite this, it is difficult to find an explanation for their failure to address outcome (technical) quality in the SERVQUAL instrument. It would seem that technical quality has been neglected in SERVQUAL's measurement of service quality.

Despite these concerns, much of the previous service-quality research has concentrated on the SERVQUAL instrument, and has thus focused on the functional-quality dimension. Few, if any, efforts have been made to test a two-component model of service quality that includes both technical quality and functional quality. Subsequently that outsourcing is basically ethical and it can be used as a positioning strategy in China. However, there is some evidence to suggest that outsourcing and favor are sensitive and situation-specific, but further research is needed to confirm these claims. The purpose of the present study is therefore to extend understanding of outsourcing by empirically examining a conceptualization of service quality that includes both technical quality and functional quality.

\section{The Concept of QMP service performance}

According to Hassan and Kerr's, (2003) study found that the total nine dimensions of TQM n service organizations have been conceptualized from the literature. The dimensions are leadership, strategic planning, customer and market focus, information and analysis, human resource development and management, and process management - all leading to the achievement of ever improving performance. The frameworks clear 
that these quality dimensions will enhance the organizational performance which comprised productivity and quality, scheduling and delivery, financial results and customer satisfaction performance. Quality dimensions are independent variables, and performance measures are dependent variables. The four organizational performance measures can be operationalised as in table 1 below.

\begin{tabular}{|l|l|l|}
\hline Independent variables & Dependent variables \\
\hline $\begin{array}{l}\text { leadership, } \\
\text { strategic planning, } \\
\text { customer and market focus, information and } \\
\text { analysis, } \\
\text { human resource } \\
\text { development and management, and } \\
\text { process management }\end{array}$ & $\begin{array}{l}\text { productivity and quality, scheduling and } \\
\text { delivery, financial results and customer } \\
\text { satisfaction }\end{array}$ \\
\hline
\end{tabular}

Table: 1

Every independent variable (dimension of quality) will measured by a number of items. The measurement items for a particular dimension will be averaged to get a summary score for that dimension. Organizational performance measure will be measuring by average the score for the items under performance measure.

Thus researchers have been undertaken in other sectors, service organizations have largely been overlooked (Abernethy \& Stoelwinder, 1991; Sharma, 2002; Chenhall, 2003; Auzair \& Langfield-Smith, 2005). Hence, in an attempt to fill this gap, these studies explore the requirements on PMS design from the service organization perception. Considering the dynamic business environment, the studies suggest that contemporary as opposed to traditional PMS shall be pertinent in managing service organizations. Although previous studies have explored other aspects of PMS characteristics (Chenhall \& Langfield, 1998; Lilis, 2002), the focus has generally been on the impact, owing to the use of comprehensive measurement (e.g. financial/non-financial measures, ex-ante/post-ante measures, and quantitative /qualitative measures) on the individual, group or organizational performance. Only recently, have a few empirical studies (Hoque \& James, 2000; Malina \& Selto, 2004; Chenhall, 2005; Henri, 2006) attempted to explore the issue of PMS design.

Thus from analyzing the literature studies highlight that retailing industries has changed rapidly and dramatically in terms of work maturity, increased competition, organizational roles, internal and external factors, technology tools, introduction of national/ international awards and many others. However as refer to Fry's et al., (1993) study found that organizations have encountered dramatic competition due to improved product quality, increased flexibility and reliability, the expansion of product variety, and an emphasis on innovation. In addition also on the business features that functional quality may be even more important than technical quality as it reveals the service character of retailing (Gro"nroos 1988, 1990). Company's performance may be jeopardized if its partners do not achieve an expected performance. Thus, performance depends on the effectiveness of business-oriented relationships with a clear interdependence between partners (WINNER et al., 2005). In this case, interdependence between companies occurs when the involved parts in the relationship are integrated among themselves. Therefore, they state that the company's abilities are influenced not only by internal activities, but also by partners' activities, including suppliers, other partners and clients. In the service analyzed, exporters and suppliers of international maritime transport have the delivery performance overlapped between transporter and exporter. This occurs because the direct responsible for the delivery is the transporter. However, the final client usually evaluates delivery performance as an exporter's attribute. The new challenges of the retailing firms demand that organizational managers consider appropriate paradigms of performance measurement to promote managerial improvement.

A research model is proposed to recognise the content - structure - result approach to the organizational performance of outsourcing in retailing. In subsequent the details of network decision performance measurement of retails. In following a theoretical framework of QMP organizational performance measurement presented.

\subsection{Research on QMP influences retails}

Research on service quality and quality management practice has progressively increased since the 1980s, when companies start to identify the benefits of mutual relationships within and beyond their own organizations (Holmuld, 2007). However, Woan-Yuh et al., (2007); Han, et al.,(2007); Arumugam, et al.,(2008) claim that research on quality management practice and retails is not a current fact. The comprehensive investigation and demonstration of quality-activities interdependence was conducted by Liyin, (2005), was documented in service industrial.

In past, numerous studies have addressed different features of retails and quality management practice (QMP). From 1970s, research on services emphasized mass servicing with a minimization of services costs as the key operation focus (Lee et al., 2009; Masahiro \& Yoshida, 2005).Its consideration the development of 
service requirement planning and investment in work-in-progress record could minimize servicing costs and improve quality.

However in 1990s, rigorous competition among world-class organizations brought the focus of retails and quality management practice toward better operating performance indicates lower defect rates, reduced cost of quality, higher productivity, on-time delivery and customer satisfaction. The developments of QMP model for instance the improvement of servicing efficiency and closest to the customers and able to influence how the customers perceive interactions with the company. In subsequent, organizations adds their performance of best practice to corporate management resources, retailing functions and strategic suppliers (Gryna, et al.,2007; Yuen, 2006; Neely et al.,1995, 1996).

This shifts production and output towards the customer perceptions that embraced the concepts of retails and quality management practice to improve efficiency and effectiveness across the quality management practice which form direct to research into service performance measurement (Holmlund, 2007; Yuen, 2006). Recently, research into retails and quality management practice has focused on the maturity framework of quality-activities integration to measure the success of strategic decisions within relational quality-activities (Gionato, 2008; Croom, 2000). Table 2 is a strategic decision within relational quality-activities summarizing the research to six divisions refers to Croom, (as cited in Yuen, 2006).

Table 2: principal research areas in quality-activities

\begin{tabular}{|c|c|}
\hline Strategic management & Relationships or partnerships \\
\hline $\begin{array}{l}\text { Strategic networks } \\
\text { Control in the supply chain } \\
\text { Time-based strategy } \\
\text { Strategic sourcing } \\
\text { Vertical disintegration } \\
\text { Make or buy decisions } \\
\text { Core competencies focus } \\
\text { Supply network design } \\
\text { Strategic alliances } \\
\text { Strategic supplier segmentation } \\
\text { World class manufacturing } \\
\text { Strategic supplier selection } \\
\text { Global strategy } \\
\text { Capability development } \\
\text { Strategic purchasing }\end{array}$ & $\begin{array}{l}\text { Relationships development } \\
\text { Supplier development } \\
\text { Strategic supplier selection } \\
\text { Vertical disintegration } \\
\text { Partnership sourcing } \\
\text { Supplier involvement } \\
\text { Supply or distribution base integration } \\
\text { Supplier assessment (ISO) } \\
\text { Guest engineering concept } \\
\text { Design for manufacturing } \\
\text { Mergers, acquisitions, and joint ventures } \\
\text { Strategic alliances } \\
\text { Contract view, trust, commitment } \\
\text { Partnership performances } \\
\text { Relationship marketing }\end{array}$ \\
\hline Logistics & Best practices \\
\hline $\begin{array}{l}\text { Integration of materials and information flows JIT, MRP, } \\
\text { waste removal, VMI } \\
\text { Physical distribution } \\
\text { Cross docking } \\
\text { Logistics postponement } \\
\text { Capacity planning } \\
\text { Forecast information management } \\
\text { Distribution channel management } \\
\text { Planning and control of materials flow }\end{array}$ & $\begin{array}{l}\text { Benchmarking } \\
\text { Continuous improvement } \\
\text { Tiered supplier partnerships } \\
\text { Supplier associations } \\
\text { Leverage learning network } \\
\text { Performance measurement } \\
\text { Quick response and time compression } \\
\text { Process mapping and waste removal } \\
\text { Physical vs. market-oriented supply chain }\end{array}$ \\
\hline Marketing & Organizational behaviour \\
\hline $\begin{array}{l}\text { Relationship marketing } \\
\text { Internet supply chains } \\
\text { Customer service management } \\
\text { Efficient replenishment } \\
\text { After sales service }\end{array}$ & $\begin{array}{l}\text { Communication } \\
\text { Human resources management } \\
\text { Employee relationships } \\
\text { Power in relationships } \\
\text { Organizational culture } \\
\text { Organizational learning } \\
\text { Technology transfer } \\
\text { Knowledge transfer }\end{array}$ \\
\hline
\end{tabular}

Source: Yuen, (2006)

Research into retails and QMP usually stress on perception: coordination and organizational arrangement. In current coordination, companies coordinate cash capital, information and facilitate physical in the quality management practice to maximize effectiveness, adaptive and efficiency (Holmuld, 2007). In subsequent, organizational arrangement, companies that are meets with increasing competition interact and imitate with suppliers and customers to increase customer service, supplier response and lessen operation costs. Indeed influences of the outsourcing, companies coordinate physical instruments, information, supplier relation network to increases efficiency and effectiveness include inventory stock.

\subsection{INSTRUMENT COMPARISON}

Based on literature, Table 3 and Table 4 show the quality management practices in manufacturing, services and higher education based on studies which have analyzed the quality measurement instruments. 
These instruments generated from the key factors for successful quality management implementation. According to Abdullah, et al., (2008), these factors have been provided by contributions from quality leaders, formal evaluation models and measurement studies. Most of these authors show some common issues which can be considered as critical for successful continuous quality improvement efforts.

According to these studies, the most commonly used in literature on quality management are the following: top management leadership; strategic planning; customer focus \& satisfaction; analysis and information; employee involvement; people management; education and training; human resource management; process management; supplier management; impact on society; and results/business results. According to Venkatraman (2007); Masahiro Miyagawa and Kosaku Yoshida,(2005); and Srikanthan and Dalrymple (2002), using those direct investment resources, many joint ventures and foreign owned companies have started operations in China. However, it was found that there were many quality problems in the operations. Within the context of successful TQM implementation, there is increasing recognition of the importance of human factors in quality management. It is reported that one of the biggest business risks for Japanese owned companies surveyed in 1995 was the "quality problem" (Huang, 2003:Sun 2000) comparison made by many researchers between the industry, service and education, have pointed out that although industry and service differ from business process perspectives, some of their outcomes such as focussing on building flexibility and improving customer base in a dynamic environment are very much similar.

In general there is no different on general dimensions of QMP practices in manufacturing, services and higher education (Table 3 and Table 4). The different basically on the term used and modification of dimension made to suit that particular industry or organisation. For instance, some organisation used the term "Leadership", while other organisation used "Management Commitment". Literate shows that although they are using the different term, but they are actually talking about the same thing. Another example is "Human Resource Management" and "Staff Focus", also focusing on the same thing although different term used. Some organisation tailored the dimensions to suit their nature of businesses. For instance, dimension used in education is course delivery, while in manufacturing and services are product delivery and service delivery.

Table 3: quality management practices according to measurement instruments in manufacturing and services

\section{Study}

Fotopoulos, and Psomas (2009)

Das, Paul, and Swierczek, (2008)

Jayamaha, Grigg, and Mann (2008)

Ooi, Abu Bakar, Arumugam, Vellapan and Loke, (2007)

Miyagawa, and Yoshida, (2005)

Baidoun, (2003)

\section{Quality management measures}

Top management commitment; Strategic quality planning; Employee involvement; Supplier management; Customer focus; Process orientation; Continuous improvement; Factsbased decision making; and Human resource development. Top management commitment; Supplier quality management; Continuous quality improvement; Product innovation; Benchmarking; Employee involvement; Reward and recognition; Education and training; Customer focus; and Product quality.

Senior leadership; Governance and social responsibilities; Strategy development; Strategy deployment; Customer and market knowledge; Customer relationships and satisfaction; Measurement and analysis of organizational performance; Information and knowledge management; Work systems; Employee learning and motivation; Employee wellbeing and satisfaction; Value creation processes; Support processes; Customer-focused results; Product and service results; Financial and market results; Human resource results Organizational effectiveness results; and Governance and social responsibility results.

Reward and recognition; Customer focus; Organizational culture; Organizational trust; and Teamwork.

Leadership; Information; Strategy; Human resource; Quality assurance; Supplier quality; Quality and operational results; Customer focus and satisfaction; and General matters.

Leadership and top management commitment; People management; Middle management involvement; Training and education; Rewards and recognition; Teamwork; Quality policy and strategy; Communicating for quality; Supplier management; Accredited QMS; Organizing for quality; Managing by processes; Benchmarking; Self-assessment; Cost of quality; Quality control techniques; and Measuring customer wants and satisfaction.

Top management leadership; Role of the quality department; Training

Product design; Supplier quality management; Process management; Quality data reporting; Employee relations; 
Conca, et al., (2004)*

Fco. Javier Llore'ns Montes, Antonio Verdu' Jover and Luis Miguel Molina Fernández (2003)

Sohail, and Hoong, (2003)

Brah, Tee, Rao, (2002)

Sharma, and Gadenne, (2002)

Note: * Source: Abdullah, Jegak Uli and Tarl', (2008)
Customer satisfaction

Leadership; Quality planning; Employee management; Supplier management; Customer focus; Process management; Continuous improvement; and Learning.

Managerial leadership and commitment; Human resources management; The relationship with customers and suppliers; The internal culture of the organization; and The process management.

Employee training and development; Process management; Quality measurement and benchmarking; Top managemen commitment; Customer involvement and satisfaction; and Strategy and planning.

Corporate planning; Role of top management leadership; Customer focus;

Human resource focus; Process focus; Quality focus; and Information and analysis.

Increasing organization "s personal contacts with customer Increased employee interaction with customers and suppliers; Increased employee involvement in design and planning; Increased employee autonomy in decision making; Top executives actively championing our quality program; Employee training in quality principles; Use of statistics methods to measure and monitor quality; Use of charts and graphs to measure and monitor quality; Employee training in statistical methods for measuring quality; Managemen training in quality principles; Use of empowered empowerment; Employee involvement; Employee training; Product quality; and Supplier performance.

\section{Table 4: quality management practices according to measurement instruments in retailing}

\section{Study}

Mehra, and Rhee, (2009)

Sahney, Banwet, Karunes, (2008)

Toremen, F., Karakus, M., Yasan, T., (2009)

Joiner, T. A. (200 7)

Sakthivel, and Raju, (2006)

David \& Stanley, (2000)
Quality management measures

Student empowerment; Creation of teamwork environment; Team self-management; and Self-confidence and teammate trust.

Emphasis on continuous improvement; Differentiation; Customer focus; Budget priorities; Well-defined channels of communication; Effective and efficient leadership; Clear and specific policies and procedures; Instructional competence; Management-by-fact/information system; and Strategic and operational planning.

human focused approach, TQM can make importan contributions to the increase of quality of education and the improvement of educational organizations

co-worker support and organization support moderated the relationship between TQM implementation and organization performance.

investigate the cultural influences in implementing an effective TQM program so that a comprehensive picture of the engineering education across different cultures and multiple service settings in the world scenario would emerge.

The ethics concepts of trust, responsibility, and integrity are part of the value system of total quality.

\section{Developing Qmp Measurement Instrument In Retailing}

Among the researchers, there is a consensus that QMP is a way of managing an organisation to improve its overall effectiveness and performance. There is less agreement as to what the primary constructs of QMP are, or what the overall concept of QMP is. No uniform view of QMP exists today. So far, QMP has come to mean different things to different people (Zhang, et al., 2000).

QMP constructs in retailing discussed in the literature vary from author to author, although there are common themes formed by the following requirements: leadership; strategy planning; customer focus; measurement, analysis \& knowledge management; people management; and process and system management (;Fotopoulos, and Psomas (2009), Das, Paul, and Swierczek, (2008); Jayamaha, Grigg, and Mann (2008); Ooi, Abu Bakar, Arumugam, Vellapan and Loke, (2007); Miyagawa, and Yoshida, (2005). Through a prescriptive 
conceptual, empirical and practitioner literature review we have identified the following seven QMP implementation constructs:

1. Supplier quality

2. Support of human resource development

3. Customer focus

4. Process approach/strategy plan

5. Customer focus and satisfaction

6. Quality information and analysis

7. Employee participation and labour union issues

8. Leadership

\section{$1 \quad$ Supplier quality}

A supplier quality is an evaluation of the ability of a supplier's quality system to meet quality requirements on production lots, e.g., to prevent, identify, and remove any product that does not meet requirements. The results are used in the supplier selection process, or, if the supplier has already been chosen, alert the purchaser to areas where the supplier may need help in meeting requirements (Gryna et al., 2007).

\section{Support of human resource development}

A basic activity in the service industries is the service encounter, e.g., the contact made with the client when meeting a customer's need. Overall the quality of the transaction involves both the technical sufficiency of the result and the social skills of the 'frontline' person who conducts the transaction. The investment in selection, training, and empowerment of employees can lead to the fulfilment of a company's target - act to meet customer needs (Jeffrey 1995). The service encounter goes beyond "speed, content, and attitude".

\section{3}

\section{Customer focus}

Decision made during design is the dominant influence on product costs, the ability to meet specifications, and the time required to bring a new product to the marketplace. This type examines the key aspects of process management, including learning-focused quality design, delivery, services and business operations (Gryna, et al., 2007). It should examine how key processes are innovatively designed, effectively managed and continuously improved. The performance results of this element would examine customer performance and improvement using key measures and indicators.

Process approach/strategy plan

Regard to Harrington (1991), Strategy plan is a guide on how to pursue the organization's mission and vision. Strategies set direction by identifying the key issues or activities that help develop specific goals and plans. Strategies must contribute significantly to the vision. In developing strategies and goals, leadership of top / middle management is needs. This scope provides a source of valuable ideas and also encourages provider for implementation.

\section{$5 \quad$ Customer focus and satisfaction}

These cover many facts of product or can discuss only quality. A discussion can be broad (e.g., obtaining views on customer needs) or can have a narrower scope (e.g., determining customer sensitivity to various degrees of surface imperfections on silverware). Those consist of customers from various market segments, or noncustomer segments the firm wants to penetrate. Sessions can provide depth of information on customer needs, expectations, perceptions, satisfaction, intentions and reactions to new concepts or ideas. This type stresses relationships as an important part of an overall listening, learning, and performance excellence strategy (Gryna et al., 2007). Therefore, the type examines how the organization builds relationships with customers and providers and determines the key factors that attract customers and lead to customer and provider satisfaction

Quality information and analysis

Basic to the concept of diagnosis is the factual approach - the use of facts, rather than opinions, to reach conclusions about the causes of a quality problem. Obviously in practice the importance to take action on a dramatic problem often results in premature (and incorrect) decisions (Juran, et al., 1998).

Tops / Middles management develops the strategies for quality and ensures their implementation through personal leadership. This role include establishing, aligning, and deploying quality goals and strategies and then serving on leadership team to lead the quality effort. Indeed new roles, which include coaching and 
developing teams and individuals, clarifying business expectations and responsibilities, managing the interface between teams and their environment, allocating resources among teams, and ensuring that continuous improvements are occurring. All of this represents a span of responsibility greatly increased beyond that of the traditional supervisor. Managers make provision for everyone's input to decisions affecting the larger organization, and for participative planning processes at the functional level Netas, (1995).

\section{$8 \quad$ Employee participation and labour union issues}

The principles of selection, training, and retention of personnel are known but are not always practiced with sufficient intensity in many activities. To ensure action on quality, a starting point is to provide quality goals and measurements at all levels. Clear quality goals for individuals are important stimuli for inspiring superiority in quality. Human beings commit themselves in two different ways: external and internal (Argyris, 1998). Under external commitment, management defines the goals for employees and also the tasks required achieve the goals. Under internal commitment, management and employees jointly define goals, and the employees define the tasks to achieve the goals

\section{$9 \quad$ General Matters}

A mission and vision is a statement of the organization's purpose and the scope of its operation e.g., in practice, mission statements focus on "what our business is now"; vision statement emphasize "what our business will be later".

\section{Conclusion}

In adopting the outsourcing approach, outsource helps firms to utilize some, or all, of the retails activities to achieve complete services. Starting with the proposition that service quality is multidimensional, it is possible to develop a framework to illustrate the structure of service quality. Developing such a framework involves identifying the dimensions of service quality (technical and functional), and the components thought to make up each dimension. Marketing scholars have yet to identify attributes (or components) that define the technical quality dimension, although it is widely accepted that technical quality significantly affects customers' perceptions of service quality (Gro"nroos, 1982, 1990; Rust and Oliver, 1994). More important that OUT is a relationship between management commitment to effective employee involvement and effectiveness of employee involvement affects customer perceptions of service performance and employees' job satisfaction. Outsourcing firms provide inventory improvements and develop efficiency, and detain the market level that result the higher volumes that are obtained by the aggregation of demand across a large market.

Therefore each retailing can then use this to develop its objectives and strategies that transfer to operation phrases as core of retailing resources to fulfil each member daily task, focus on its retailing mission and vision, apply a strategy of major breakthrough, and promote service quality because high service performance can satisfy customer requirement and overcome customer expectations.

\section{Reference:}

[1]. Anderson, J. C., Cleveland, G., and Schroeder R. G., (1989). Operations Strategy: A literature review, Journal of Operations Management, 18 (2), 133-158

[2]. Hofstede, G. (2001), Culture's Consequences: Comparing Values, Behaviors, Institutions and Organizations Across Nations, Sage, Beverly Hills, CA.

[3]. Cronin, J.J. and Taylor, S.A. (1992), "Measuring service quality: a re-examination and extension”, Journal of Marketing, Vol. 56, July, pp. 55-68.(1)

[4]. Brown, T., Churchill, G. and Peter, J.P. (1993), "Research note: improving the measurement of service quality", Journal of Retailing, Vol. 69, Spring, pp. 127-39 (1)

[5]. Rust, R.T. and Zahorik, A.J. (1993), "Customer satisfaction, customer retention, and market share”, Journal of Retailing, Vol. 69 No. 2, Summer, pp. 193-216. (1)

[6]. Greising, D.(1994), Quality: How to Make It Pay, Business Week August 8, pp. $54-59$ (1)

[7]. Carman, J. M. (1990). Consumer perceptions of service quality: An assessment of the SERVQUAL dimensions. Journal of Retailing, 66, 35-55. (1)

[8]. Finn, D. W., Lamb, Jr., C. W.(1991), "An evaluation the SERVQUAL scales in a retail setting, in: Holman," R. H., Solomon. M. R. (Eds.), Advances in Consumer Research, Vol. 18, Association for Consumer Research, Provo, UT (1)

[9]. Brown, T. 1.. Churchill. G. A. Jr., Peter, J. P.(1993), "Improving the measurement of service quality," Journal of Retailing, Vol. 69, No.1, pp. 127- 139. (1)

[10]. 1 Maria Holmlund, (2007). Suggesting and Comparing Different Scopes on Quality Management: Production, Service, Relationship, and Network. Hanken Swedish School of Economics and Business Administration, Helsinki, Finland (1)

[11]. M. Hasan and R. M. Kerr (2003). TQM and organizational performance in service organizations. The TQM Magazine Vol.15-no 42003-286-291 (1)

[12]. Zeithaml, V.A. (1987), Defining and Relating Prices, Perceived Quality and Perceived Value, Marketing Science Institute, Cambridge, MA (1)

[13]. Brady, M.K. and Cronin, J.J. Jr (2001), "Some new thoughts on conceptualizing perceived service quality: a hierarchical approach", Journal of Marketing, Vol. 65, pp. 34-49. (1)

[14]. Parasuraman, A., Zeithaml, V.A. and Berry, L.L. (1985), "A conceptual model of service quality and its implications for future research", Journal of Marketing, Vol. 49, Fall, pp. 41-50.(1) 
[15]. Parasuraman, A., Zeithaml, V. A., \& Berry, L. L. (1988). SERVQUAL: A multiple-item scale for measuring consumer perceptions. Journal of Retailing, 64(1), 12 (1)

[16]. Asubonteng, P., McCleary, K.J. and Swan, J.E. (1996), "SERVQUAL revisited: a critical review of service quality", Journal of Services Marketing, Vol. 10 No. 6, pp. 62-81. (1)

[17]. Buttle, F. (1996), "SERVQUAL: review, critique, research agenda”, European Journal of Marketing, Vol. 30 No. 1, pp. 8-32.(1)

[18]. Babakus, E. and Boller, G.W. (1992), “An empirical assessment of the SERVQUAL scale”, Journal of Business Research, Vol. 24, pp. 253-68. (8)

[19]. Gro"nroos, C. (1990), Service Management and Marketing: Managing the Moments of Truth in Service Competition, Lexington Books, Lexington, MA. (1)

[20]. Mangold, G.W. and Babakus, E. (1991), "Service quality: the front-stage perspective vs the back-stage perspective", Journal of Services Marketing, Vol. 5 No. 4, pp. 59-70. (1)

[21]. Richard, M.D. and Allaway, A.W. (1993), "Service quality attributes and choice behavior", Journal of Services Marketing, Vol. 7 No. 1, pp. 59-68. (1)

[22]. Abernethy, M.A. and Stoelwinder, J.U. (1991), "Budget use, task uncertainty, system goal orientation and subunit performance: a test of the fit hypothesis in not-for-profit hospitals", Accounting, Organizations and Society, Vol. 15 No. 4, pp. 105-20. (1)

[23]. Sharma, D.S. (2002), "The differential effect of environmental dimensionality, size, and structure on budget system characteristics in hotels", Management Accounting Research, Vol. 13 No. 1, pp. 101-30(1)

[24]. Md. Auzair, S. and Langfield-Smith, K. (2005), "The effect of service process type, business strategy and life cycle stage on bureaucratic MCS in service organizations”, Management Accounting Research, Vol. 16 No. 4, pp. 399-421 (1)

[25]. Lillis, A.M. (2002), "Managing multiple dimensions of manufacturing performance - an exploratory study", Accounting, Organizations and Society, Vol. 27 No. 6, pp. 497-529. (1)

[26]. Hoque, Z. and James, W. (2000), "Linking balanced scorecard measures to size and market factors: impact on organizational performance", Journal of Management Accounting Research, Vol. 12 No. 1, pp. 1-17. (1)

[27]. Malina, M.A. and Selto, F.H. (2004), "Choice and change of measures in performance measurement models", Management Accounting Research 15 No. 4, pp. 441-69. (1)

[28]. Chenhall, R.H. (2005), "Integrative strategic performance measurement systems, strategic alignment of manufacturing, learning and strategic outcomes: an exploratory study", Accounting, Organizations and Society, Vol. 30 No. 5, pp. 395-422.(1)

[29]. Henri, J. (2006a), "Organizational culture and performance measurement systems", Accounting, Organizations and Society, Vol. 31 No. 1, pp. 77-103. (1)

[30]. Gro"nroos, C. (1988), "Service quality: the six criteria of good perceived service quality”, Review of Business, Vol. 9 No. 3 , pp. 1013 (1)

[31]. WINNER, A.; SZÁNTÓ, R.; KISS, N. (2005). Business Relationship Management as a Tool of Performance Management - the cases of successful Hungarian companies. EurOMAInternational Conference on Operations and Global Competitiveness. Budapest, Hungary (8)

[32]. Woan-Yuh Jang, Ching-I Lin, (2008),"An integrated framework for ISO 9000 motivation, depth of ISO implementation and firm performance: The case of Taiwan", Journal of Manufacturing Technology Management, Vol. 19 Iss: 2 pp. $194-216$ (8)

[33]. Veeri Arumugam, Keng-Boon Ooi, Tuck-Chee Fong, (2008). TQM practices and quality management performance. An investigation of their relationship using data from ISO 9001:2000 firms in Malaysia (8)

[34]. Liyin Jin, (2005). The Effects of Service Quality Management Practice on Customer Satisfaction

[35]. Peter K.C. Lee, W.M. To and Billy T.W. Yu, (2009). The implementation and performance outcomes of ISO 9000 in service organizations. An empirical taxonomy

[36]. Masahiro Miyagawa and Kosaku Yoshida, (2005). An empirical study of TQM practices in Japanese-owned manufacturers in China

[37]. Frank M. Gryna, Richard C. H. Chua, Joseph A. Deofeo (2007). Juran's Quality Planning and Analysis for Enterprise quality $5^{\text {th }}$. ed. (3)

[38]. YUEN Sheung Man, (2006). Performance Measurement and Management of Third Party Logistics: An Organizational Theory Approach

[39]. Gionata Carmignani, (2008). Process-based management. A structured approach to provide the best answers to the ISO 9001 requirements. Business Process Management (1)

[40]. Croom, S., Romano, P., and Giannakis, M. (2000). Supply chain management: An analytical framework for critical literature review, European Journal of Purchasing and Supply Management, 6, 67-83. (1)

[41]. Venkatraman, S. (2007); A framework for implementing TQM in higher education programs

[42]. Huarng, F. and Chen, Y.T. (2002), "Relationships of TQM philosophy, methods and performance: a survey in Taiwan", Industrial Management \& Data Systems, Vol. 102 No. 4, pp. 226-34. (1)

[43]. Hongyi Sun, (2000). Total quality management, ISO 9000 certification and performance improvement. International Journal of Quality \& Reliability Management. Vol. 17/2 (2000) (1)

[44]. Christos V. Fotopoulos and Evangelos L. Psomas (2010). The structural relationships between TQM factors and organizational performance. The TQM Journal Vol. 22 No. 5, 2010 pp. 539-552 (3)

[45]. Toremen, F., Karakus, M., Yasan, T., (2009); Total quality management practices in Turkish primary schools. Quality Assurance in Education, Vol. 17 No. 1, 2009, pp. 30-44, Emerald Group Publishing Limited.

[46]. Joiner, T. A. (2007); Total quality management and performance: The role of organization support and co-worker support. International Journal of Quality \& Reliability Management, Vol. 24 No. 6, pp. 617-627. Emerald Group Publishing Limited

[47]. Sakthivel, P. B. and Raju, R. (2006); An instrument for measuring engineering education quality from students' perspective. The Quality Management Journal, 13(3), 23-34.

[48]. Mehra, S. and Rhee, M. (2009); On the application of quality management concepts in education: An example of a Korean classroom. International Journal of Quality \& Reliability Management, Vol. 26 No. 4, 2009, pp. 312-324, Emerald Group Publishing Limited

[49]. Sharma, D.S. (2002), "The differential effect of environmental dimensionality, size, and structure on budget system characteristics in hotels", Management Accounting Research, Vol. 13 No. 1, pp. 101-30 (1)

[50]. David L. Goetsch and Stanley B. Davis, (2000). Quality management: introduction to total quality management for production, processing, and services/ $3^{\text {rd }}$ ed.

[51]. Zhang, Z., Waszink, A., and Wijngaard, J. (2000). There is a consensus that TQM is a way of managing an organisation to improve its overall effectiveness and performance. (1) 